Volume 1 Number 2

\title{
REVOLUTIONARY UNDERPINNINGS IN POETRY: A STYLISTIC ANALYSIS OF OSUNDARE'S THE EYE OF THE EARTH
}

\author{
Joshua, Ali Diko \\ Department of English, \\ Ibrahim Badamasi Babangida University, \\ P.M.B 11, Lapai, Niger State. \\ Email: joshalidik@gmail.com \\ Contact: $08038989515 ; 08055838373$. \\ Saba, Lucas, \\ Department of English, \\ Ibrahim Badamasi Babangida University, \\ P.M.B 11, Lapai, Niger State. \\ Email: $\underline{\text { saba4u27@yahoo.com }}$ \\ Contact: 07012476719; 07064879846.
}

\begin{abstract}
Language, whether written or spoken, is used for different purposes by man. The textual function of language makes it possible for writers especially poets to lend their voice to local, national and international matters of interest through written poetry. In most cases, poetry functions more than being just a mirror to the society; it has the implicit intent of causing a change, thus, it is underpinned with criticisms that could incite revolution in readers which could upturn the status quo. The intention is to awaken readers to the reality and to critically engage their mind in order to make a rethink so as to see the 'evil' behind the 'good' in the society. The data for analysis were purposively selected from Osundare's poetry collection The Eye of the Earth. Stylistics was deployed as the theoretical framework to analyse the selected data while, Blending Theory was deployed to unearth the meaning-making process in the analysed data. From the analysis, different stylistic devices used such as simile, rhetorical question, metaphor, parallelism etc. reveal societal ills and condemn apathy in readers with the aim of inciting revolution towards having an egalitarian society. The study found out that new meaning is created through blending of concepts from different input spaces. A general and common ground is derived from the input spaces which are used to derive new meaning. This linguistic dexterity is intended by the poet to project his message to readers in a subtle way. The study concluded that Osundare's The Eye of the Earth contains implicit revolutionary nuances aimed at motivating readers to rise against the injustices in the society towards achieving an egalitarian society. Also, the poet decries man's injurious activities to nature and opts for preservation of natural endowments thus, the aim of this study is achieved which is to unearth the revolutionary nuances embedded in the selected and analysed data. Apart from its contribution to existing literature especially in communication, this study presents a methodology and a theoretical framework that is helpful in the appreciation of literary writings.
\end{abstract}

Keywords: Blending, mapping, style, stylistics, revolution, masses, leaders, stylistic devices, input spaces

\section{INTRODUCTION}

Poetry serves as a mirror to the society as poets use it to portray various activities of the society. Language as a potent tool to poets lends itself to creative manipulations as an exploration of the linguistic plurality to capture the changing dynamics of the society and diverse linguistic needs of the speaker in different contexts. Since language could easily lend itself to creative manipulations, it could be seen as a tool that could be used to condition people's thoughts. From the colonial era, poetry has often served as a means to reveal societal ills in a bid to correct them. There have been calls to pay attention to the emerging challenge of the depletion of the ozone layer and the environment in order to address issues of environmental degradation and global warming. Osundare's The Eye of the Earth could be 
seen as response to those calls as its focus lies in the call for preservation of nature's endowments. The Eye of the Earth is a collection of poems. It is divided into three sections: "Back to Earth", "Rainsongs" and "Homecall. It presents various themes ranging from the unhealthy activities of man on the earth to the presentation of the earth as a repository of wealth for man's judicious use. It portrays Osundare's perception of the earth in relation to man's activities and the effects on the environment. Nature is the crux of this collection as it hinges on the celebration of the rich cultural traditions of his people and emphasizes their reverence for nature. The collection addresses issues of environmental degradation and desertification. By exploring the theme of environmental degradation and the theme of sociopolitical injustices, Osundare portrays various societal ills through the deployment of both stylistic devices to achieve his aim effectively. This study concludes that revolutionary poets do more than informing readers about the various happenings in the society; through their poems, by carefully deploying both stylistic devices, they unearth societal ills aimed towards challenging the people to rise up and fight for their freedom. This study reveals that the poets as writers are also 'righters' who seek to correct societal ills, injustices and other social vices using poetry.

Deploying stylistics and blending theory to unearth the revolutionary nuances inherent in Osundare's The Eye of the Earth is very rewarding as it portrays the meaning-making process through blends using stylistic devices. This meaning-making process helps to uncover hidden revolutionary nuances inherent which are targeted towards readers in order incite revolutionary with the aim of attaining an egalitarian society and a healthy environment.

\section{THE HISTORICAL AND DEVELOPMENTAL STAGES OF AFRICAN POETRY}

Poetry as an art form has undergone several phases of evolution from pre-colonial to colonial and then to post-colonial eras in most African countries. There existed a thin line between poets and musicians as poets composed and rendered poetry in musical form. Poets rendered their works at funerals, marriage ceremonies and other ceremonial avenues where they could give their renditions, with themes focused on praising virtues and condemning vices in society. Themes of liberation, independence and negritude began to permeate African literature in the late colonial period when Africa began to seek independence from the colonialists. African poets (as well as playwrights and novelists) began to write condemning slavery and colonialism and advocating for self-rule. African literature at that time was protest in nature. It came as a reaction to various forms of injustices meted out on Africans by the colonial masters and later, post-colonial African masters. African poets preoccupied themselves with themes such as: the clash between Africa's past and present, between tradition and modernity, between indigenous and foreign, between individualism and community, between socialism and capitalism, between development and self-reliance and between Africanity and humanity. Other themes in this period include social problems such as corruption, the economic disparities in newly independent countries, and the rights and roles of women.

These themes explored by the writers are a reflection of what is happening in the society. Hence, it is obvious that literature does not develop in a vacuum. It is the political, economic, social and cultural events of a society that shape its literature. Indeed, it will be right to say that for any literary work to be relevant, it is necessary that it bears relevance, explicitly or implicitly, to the social milieu in which it is set (Kehinde Ayo, 2005). The various historical and developmental stages of African poetry (written) reflect the historical realities of such era; the pre-colonial, the colonial and the post-colonial and poets largely drew their themes from these eras. 


\section{STYLISTICS}

Stylistics is a word which has its origin from "Style". From the layman's point of view, style is the general way of doing something thus, we could refer to a person's style of writing, walking, sitting, dressing etc. Leech (1969) describes style as "the way in which an act is spoken, written or performed". Stylistics can be defined as the study of language usage in different contexts either linguistic or situational. Lawal (2003), posits that stylistics is concerned with the analysis and description of linguistic features of texts in relations to their meanings. It is aimed at analyzing language habits with the purpose of identifying those features which are restricted to certain kinds of social contexts. According to Simpson (2004), "to do stylistics is to explore language, and, more specifically, to explore creativity in language use". Literary stylistics is more concerned with providing "the basis for fuller understanding, appreciation and interpretation of avowedly literary and author-centred texts (Carter and Simpson, 1989). Literary stylistics helps to explore the stylistic devices used by an author to present his message. It focuses on how textuality is achieved by writers through the various literary and stylistic devices. In literary stylistics, the devices that can constitute style include figurative devices and rhetorical tropes such as simile, metaphor, rhyme and rhythm, hyperbole, personification, point of view and narrative technique, etc. Style in literature involves the investigation into the ways that an author uses words through the deployment of literary elements and devices. Issues to consider include choice of words, sentence structure and arrangement, imagery, figurative language, etc.

The approaches to style include the following:

(a) Style as choice from variant forms: The crux of this approach is that a language user makes certain choices from variant forms (an array of possible elements) and combines them to convey a particular situation. In other words, speaker selects from lexical possibilities that the language permits in order to express themselves. These choices are determined by the context of situation of the speech event. According to Osundare (2003), style as choice stands out as the most author-oriented because it transcends the arrays of physicalities of the language used to the various dynamics and imperatives that style offers. Going further, Osundare (2003) explains that the selection of lexical items and grammatical elements are chosen by the pre-verbal choice and form. He distinguishes between pre-verbal and verbal choices which cover the psychological and cultural choices and the actual use of the choices made with the pre-verbal choices greatly determining the use of the verbal choices.

(b) Style as deviation from the norm: This approach is both a rule governed behaviour and accumulation norms. Osundare's (2003:18) schema for style as difference bifurcates into variation and deviation. Variation could be code-oriented, subject-oriented or author-oriented while deviation could be extro or intro normic which branches to intra-authorial and interauthorial. Osundare (2003) explains that code-oriented variation could be lexical, syntactic, or rhetorical. Subject oriented variation covers the different fields of human activities such as law, medicine, construction, engineering, teaching, ICT, carpentry, etc. which vary with different manifestations of peculiarity based on each profession. Author oriented variation on the other hand, centres on the peculiarity of individual author In simpler language, this approach to the study of style deviates from the standard graphological, phonological, lexicon-semantic, morphological, syntactic and discourse rules language.

(c) Style as idiosyncratic and constant form: This approach states that every individual uses language in a unique way different from others. This approach is tantamount to the sociolinguistic concept of "idiolect" which deals with the peculiarity of language use of every individual. In the opinion of Osundare (2003:29), "This perspective gives style some 
attribute of a habit, a trait, a linguistic behavior that, through settled practice, has become the hallmark of a language user or a domain of linguistic experience."

\section{THEORETICAL FRAMEWORK}

Here, the theoretical frameworks on which this study is based are presented.

\section{The Concept of Marxism}

The German philosopher, Karl Marx propounded Marxism. According to Asika (2014), Marxism is the economic and political theory originated by the German political philosopher Karl Marx that actions and human institutions are economically determined, that the class struggle is the basic agency of historical change, and that capitalism will ultimately be superseded by communism. Karl Marx believes that in production, there is the exploitation of the lower class group by the privileged class (bourgeoisie). It therefore tries to uncover these exploitations with the aim of encouraging a revolt by the exploited class against the exploiters, the masses against the bourgeoisie, the poor against the rich, etc.

Class struggle is the crux of Marxism. It aims at bringing to the fore, the unfair and exploitative conditions with the aim of concentrating the wealth of the society in the hands of its producers. Marxist writings are revolutionary in nature and are written with the aim of raising a consciousness of exploitation, inequality and injustices of those in privileged positions in the society. Marxists are preoccupied with injustices in the society and how to create a change in the status quo so as to create a balance especially in the distribution of society's wealth. Ngugi (cited in Asika, 2014) commenting says: '...It can either evidence a consciousness that seems to consciousness congruent with the interests of the oppressed class which is engaged in the struggle to change the social status quo."' (472)

Marxism x-rays the structure of the society to unravel areas of imbalances between the rich leaders versus the poor masses, the upper class versus the lower class, the bourgeois class versus the proletariats (the poor peasant masses), producers of labour versus workers etc. in order to address these imbalances. This is done in various areas of the society; economic, political, and social. Marxism achieves its aim through literature by using writings (poetry, drama, and novel) to scrutinize the different strata of the society in order to create awareness in the masses and the oppressed in the society about the injustices in the society and how they need to throw off the yoke from off their shoulders by opposing and overturning the political, social and economic strata of the society so that there will be equality regardless of one's social, political or economic stance.

\section{Blending Theory}

This theory is also known as conceptual blending theory or conceptual integration. Though a new theory, it draws from existing theories and models. Its main proponents according to Abrams (1999) are Fauconnier and Turner (1998, 2002) with contributions from other scholars like Coulson (2001, 2006), Coulson and Oakley (2000), Grady (2005), Grady, Oakley and Coulson (1999) and Sweetser (2000) among others. It is a theory derived from blending Conceptual Metaphor Theory (CMT) and Mental Spaces theory (MS) but has now developed into a fully-fledged theory independent of both theories. It blends the notion of spaces from mental Spaces Theory and the notion of mapping between spaces from Conceptual Metaphor Theory. Norgaard et al (2010:60) attempted to define it as 'an understanding of concept $\mathrm{A}$ in terms of concept $\mathrm{B}$; it is the understanding of some conceptual domain in terms of another conceptual domain' which is realized at the cognitive level rather than the sentence or word level. This theory in order to construct meaning through the blend 
comprises two (or more) input spaces, the generic space and the blend. The input spaces are the various areas that the blend is derived from which are according to Coulson (2006:190 cited in Abrams, 1999) typically structured by information from discrete cognitive domains.

The generic space is the interface among the various input spaces; it contains some components common to all the inputs while the blend which is the end point is created as a new and independent space which derives a new meaning generated from the generic space which is also generated from the input spaces. According to Norgaard et al (2010) blending theory has become a theoretical proposition firmly embraced by practitioners of stylistics, which is not surprising considering the particularly creative nature of literary discourse and its inclusion of novel blends. The researcher chose this theory to analyze Niyi Osundare's poetry collection The Eye of the Earth because in concurrence with the position of Norgaard et al above, the theory affords the researcher the opportunity to investigate the literary and stylistic creativity of the author.

Marxism as presented above is a theory that investigates society's socio-political and ethnoreligious aspects in order to bring to uncover areas of oppression, injustices and inequalities meted out on especially society's less-privileged and downtrodden especially by those in authority. This theory is significant to this research as it enabled the researcher to explore the "The Eye of the Earth" by Osundare to bring to the fore the revolutionary forces inherent in them. More so, in order to look at the language and style of the author, the researcher adopted literary stylistics as an approach in order to look at the language of the poet and to bring out the stylistic (figurative and literary) devices used in order to unravel nuances of oppression and injustice in the society. The data analysed were purposively selected from the poetry collection.

\section{ANALYSIS OF OSUNDARE'S THE EYE OF THE EARTH Simile}

Simile compares two people or things directly. It is a comparison between two distinctly different things which is explicitly indicated by the word "like" or "as". M.H Abrams (2005). This is the indirect comparison of two objects, people, animals etc. by placing them in contrast to each other.

\section{Simile in The Eye of the Earth}

(1) I have seen

"... laboring mouths famish like desert basins." (What the Earth Said, line 19-20)

(2) I have seen foremen soulless like their whistling whip. (What the Earth Said, line 1516)

(3) I have seen

Lives snuffed out like candles in the storm. (What the Earth Said, line 27-28)

Osundare in the above datum makes use of simile through the use of 'like'. The author through simile compares the situation of 'mouths' (a synecdoche for persons/people) to that of the desert. Here, the situation of people referred to in the above is likened to that of desert basins. Through this simile, Osundare creates a blend which is a new meaning. The input spaces would be 'mouths' (people) and 'desert basins'. A cognitive attribute of 'desert basins' is used to comprehend the domain of 'people' thus, giving rise to a novel meaning called the blend derived by mapping attributes of 'desert basins' unto laboring 'mouths' which refers to people. 'dryness" and "abandonment"' as attributes of "desert basins" are mapped unto those working class (laboring) people which means that the masses who y 
are left with very little to live on. Meaning that, the masses that constitute the working class live in penury. In datum 2, the input spaces are foremen' and "(whistling) whip" to generate a blend by mapping attribute of 'whip' to foremen. The blend created is that just as the 'whip' through whistling sound continues to go up and down the back of the recipient, so do foremen continuously torment the masses in their hostage.

Also, in datum 3, an attribute from the input space (candles) is mapped unto the input space; lives (people) to create a blend to mean that as 'suddenly' and without thought' as light goes out of candles in the storm, so does death come on the masses suddenly and the killers do this without hesitation. This means that the lives of the masses mean nothing to the 'killers' and can be suddenly taken anytime. Using simile to create blends as analysed above, the author is able to project his message of revolutionary instincts by portraying the horrendous ordeal of the masses; poverty, torment and death (datum 1,2, and 3 respectively) in the hands of privileged few in the position of power in the society. Through this, Osunadre decries the inhuman treatment being incessantly meted out to the poor masses by few people in the position of power.

\section{Parallel Construction/Parallelism}

Parallelism is the use of similar words or structures in successive lines. Parallelism according to Okunowo, Y. (2012) 'is a linguistic phenomenon, which explains the relationship that may be understood between units of linguistic structures, which are constructed parallel to each other or related in some other ways." Also, Myers and Simms (1989:223) define parallelism as "a rhetorical device of grammar in which words, phrases, clauses or ideas of equivalent value share a similar grammatical structure to create an inherent comparison among them.

\section{Parallel Construction/Parallelism in The Eye of the Earth}

(4) (for) earth is where we stand Earth is where we strive. (The Rocks Rose to Meet Me, St.5 line 3, 4)

(5) ...this earth is:

Ours to work not to waste

Ours to man not to maim (Ours to Plough, Not to Plunder,St.6 line 2,3)

(6) I have seen

Labouring mouths famish like desert basins

I have seen

Factory lords roll in slothful excess

I have seen

Backs creak on heartless machines

I have seen

Lungs powered with asbestos death

I have seen

Lives snuffed out like candles in the storm.

("What The Earth Said")

In datum 4, the parallel construction ' 'earth is where we...' does not only give the poem rhythm but also communicates the author's message of the valuableness of the earth to mankind due to its multiple uses. By using the input spaces "stand" and "strive", a blend is created that earth serves multiple uses to mankind hence, the need to preserve it. Through parallelism, Osundare reminds us of the importance of the earth and advices us against unwholesome practices on it. This stance of the author is clearly understood in another 
Volume 1 Number 2

parallel construction in datum 5, 'ours to... not to..." clearly decrying, through the input spaces '"work (not waste)" and 'man (not maim)", the unwholesome practices of 'wasting' and 'maiming' the earth we are to work and man.

Parallelism in datum 6 lies in the repetition and sameness of structures enhanced by the graphological arrangement of the subject-verb "I have seen". This parallelism using repetition and structural equivalence helps to provide the poem a certain rhythm which helps the poet to build up the mood of sadness through the various inhuman treatment meted out on the poor masses as listed in the poem. The input spaces are "the laboring mouths (masses)" and their "lords or foremen". Through these input spaces, Osundare creates a blend through parallelism that the poor masses who are used to do various arduous works under very horrendous treatments by the same lords they work for in addition, continue to wallow in penury while the lords have in excess. The horrendous treatment of the poor masses continues to increase and sometimes leads to death; this is evident in the parallelistic crescendo of the horrendous treatment of the masses culminating at death.

\section{Personification}

Personification is a figure of speech used to animate inanimate objects. According to Wales (2001:294), personification is "a figure of speech or trope in which an inanimate object, animate non-human, or abstract quality is given human attributes. It involves the transfer of attributes of living things to non-living things. It involves giving life to non-living things so that they are meant to act like living things.

\section{Personification in The Eye of the Earth}

(7) uncountable seeds lie sleeping in the wombs of the earth. (Harvestcall, St.8 line 1)

(8) Lynched

The lakes

Slaughtered

The seas

Mauled

The mountains (Our Earth Will Not Die, line 1-6)

In datum 7 above, the human attributes 'sleeping' and 'wombs' are attributed to 'seeds' and 'earth' respectively to bring alive the unharnessed (sleeping) earth's myriads of resources that are buried (wombed) in the earth. The input spaces are 'seeds (lie sleeping)' and '(wombs of the) earth' which create the blend that the earth houses so much that is left unharnessed by the people who are complaining of insufficiency. This means that if we put our fingers to work, there will be no lack in the land. Through personification as shown above, Osundare condemns the laziness of the people which has led to scarcity in the land whilst the earth houses so much. This is aimed at reminding the people of the abundant earth's resources and to motivate them to shun laziness and harness these resources for man's benefit.

Through personification in datum 8 above, objects are given human attributes thus, we picture the 'lakes', 'seas' and 'mountains' as though they are human beings who have been 'lynched', 'slaughtered' and 'mauled'. The input spaces 'lakes', 'seas' and 'mountains' preceded by 'lynched', 'slaughtered' and 'mauled' represent earth's natural resources used together with the verbs 'lynched', 'slaughtered' and 'mauled' create the blend that earth's natural resources suffer from unwholesome activities by man. Through this, Osundare condemns all unwholesome practices by man against natural resources and calls for a change for man to protect the earth's resources not destroy them; use them not misuse them. 
Osundare gives human qualities to inanimate objects in order to have the maximal appeal since it is to be read by human beings. He believes that it is bound to have more effect if objects are given human attributes which the people are familiar with. Personification proves very impactful especially in a revolutionary writing as this which intends to not only inform the people but to also get them to act towards change.

(9) I have seen/heard. (What the Earth Said, St.1 line 1, 4, St. 3 line 1,3, 4 line 1,3 St. 5 line 1, 3 St. 6 line 1,5)

In datum 9 above, the earth is given the human attributes of "seeing" and "hearing" by the author. This is done to make the earth feel as a human all the abuse and misuse it is being put into by having the painful experience of seeing and hearing them. The use of this personification is to tell how devastating man's activities are to the earth that even the earth which is inanimate could "see" and "hear" them. Through this, the author seeks to not only highlight these abusive acts and misuse the earth is put into but also condemns them and appeals to the people to protect the earth and its myriads of endowed natural resources rather than destroy it.

\section{REPETITION}

This is to reiterate what is earlier stated for certain reasons and to achieve certain effects. Usually, a word, phrase, sentence etc that has been used is repeated by the writer intentionally to achieve a purpose. It is an emphasis necessary to fix the attention of the reader on the keyword of the utterance.

\section{Repetition in The Eye of the Earth}

(10) Where are they? (Harvestcall, St.8 line 1,5,8,11,14)

In datum 10 above, through repetition and rhetorical question, Osundare emphasizes the blessedness of the land endowed with myriads of resources and fertility of the soil and further questions the disappearance of these things from the land. Through this, rhetorically asking the people is a pointer that the people know the whereabouts or are the cause of the disappearance of those natural endowments.

(11) They (too) are the earth. (They Too are the Earth, St.1line 1, 4, St. 2 line 1, 4, St. 3 line 1, 4, St. 4 line 1, 4)

In datum 11 above, through repetition, the author emphasizes his message. The input spaces are "they" and "earth". An attribute of "earth" ("dust" from which everybody was made regardless of colour, age, education, riches, etc.) is mapped unto "they" a particular group of people. Through this repetition, the author emphasizes that everybody is equal being all made from dust. This creates the blend that nobody should be looked down on because of one material possession or the other as ultimately, everybody is equal and has the same fate of life and death. The author, through this repetition explores the theme of inequality in the land and further condemns it. This is intended to make the so-called rich and powerful people who oppress others to stop and think on the sameness of fate of everybody and stop oppressing the masses.

(12) I have seen/heard. (What the Earth Said, St.1 line 1,4, St. 3 line 1,3, 4 line 1,3 St. 5 line 1,3 St. 6 line 1,5)

In datum 12 above, through the use of the repetition "I have seen/heard", the author personifies the earth so as to be able to "see" and "hear" the numerous abusive acts and misuse it is being put to by the people. For the earth which is inanimate to "see" and "hear", the author stylistically communicates how devastating these acts are to the earth and calls for a change to rather protect the earth and enjoy its plethora of resources. 


\section{ALLITERATION}

Alliteration as a phonetic and stylistic device provides melody and rhythm to an utterance. "Alliteration is the repetition of the initial consonants in two or more words" (Wales, 2001).The essence of this device lies in the repetition of similar sounds, in particular consonant sounds, in close succession, particularly at the beginning of successive words:

\section{Alliteration in The Eye of the Earth}

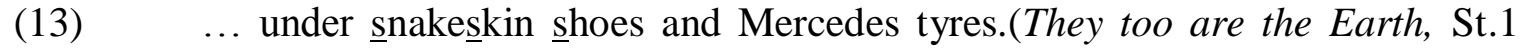
line 5) ...of gold dreams and blood banks. (They too are the Earth, St.3 line 5) ...toilwards in dreary dawns. (What the Earth Said, St.1 line 3) Foreheads foraged by grit and grime. (What the Earth Said, St. 2 line 4) Alliterations are used in the poems to give them a kind of melodic effect through the repetition of initial consonant of successive lines. For example, the repetition of the voiced labio-velar sound /w/in the initial position of the successive words gives a kind of rhythm and melodic effect to the poem (datum 17)

\section{INTERROGATION/RHETORICAL QUESTION}

Rhetorical questions are asked for emphasis or to achieve certain effect thus, no response is required. A rhetorical question according to M.H Abrams (2000:315) is a sentence in the grammatical form of a question which is not asked in order to request information or to invite a reply, but to achieve a greater expressive force than a direct assertion. This is a situation whereby questions especially rhetorical questions constitute style. These questions are more than just questions and they bear the poets' message to readers. The following are identified and analysed:

(18) Where are they? ('Harvestcall', St.6 line 1,5,8,11,14)

In datum 18 above, through rhetorical question, Osundare tells of the blessedness of the land endowed with myriads of resources and fertility of the soil and further questions the disappearance of these things from the land. By rhetorically asking the people is a pointer that the people know the whereabouts. Through this rhetorical question, the author not only questions the disappearance but indirectly blames the people for the disappearance which must have been through various activities of the people which they carry out on the land. Apart from informing readers about this disappearance, the author condemns the activities of the people which have led to the disappearance. The preceding and following lines suggest that what is referred to as "they" are the fruitful farm products ubiquitously displayed in the village as harvest time approaches which no longer exists or have greatly reduced which has caused the author great concern.

\section{with our earth so warm}

how can our hearth be so cold? ("Harvestcall” St.9 line 6,7)

In datum 19 above, the author questions the misuse of the earth's resources. This draws attention to an anomaly that the author perceives; how the earth is so blessed to yield sufficiently to benefit man but how yet, they wallow in hunger and lack. This rhetorical question also shows the author criticism of the people who by implication have either misused the earth's resources or out of laziness not used them at all which has resulted to hunger and lack in the land. The author decries abuse, misuse and underuse of earth's resources and sees lack as self-made. 


\section{METAPHOR}

Metaphor is the opposite of simile; while simile indirectly compares people or objects, metaphor on the other hand directly compares them. Metaphor describes a 'carry over.' When words are used with metaphoric senses, one field or domain of reference is carried over or mapped onto another on the basis of some perceived similarity between the two fields (Wales 2001:250). It is the transference of some quality from one object to another. Metaphor makes comparison just as simile, but unlike simile, metaphor is a direct comparison without the use of "as" or "like".

Our earth is an unopened grainhouse.

A bustling barn in some far, uncharted jungle

A distant gem in a rough unhappy dust (Ours to Plough, Not to Plunder, St.5 line 1)

In datum 20 above, the 'earth' is metaphorically "an unopened grainhouse", "a bustling barn" and "a distant gem". The input spaces are "earth" and "grainhouse", "barn" and "gem". Mapping an attribute of "grainhouse" (harbours food), "barn" (store) and "gem" (preciousness) creates the blend that the precious earth stores abundance of food for man's uses. This underscores the usefulness of the earth; the abundant useful natural resources the earth is endowed with. The author uses this to open the eyes of the masses to the earth's rich endowment if only man will work it. Through this, Osundare unearths the richness of the earth and further encourages the masses to maximize this richness by working the earth. Thus, idleness is discouraged and that lack is only a manifestation of laziness.

\section{ANTITHESIS/ANTONYMY}

Antonymy is the expression of opposite words and when the oppositeness is expressed in the entire constructions or ideas, it is called antithesis. Antonymy according to Wales (2001) refers to contrasts in meaning or opposition in meaning. Antithesis is the use of structures that have sharp contrast. This is done by a writer to achieve certain effects which synonyms might not actually express i.e. by using that, he is able to pass his message effectively to the readers. The following have been analysed:

I have seen

...native executhieves hold fort for alien wolves. ("What the Earth Said", line 18)

In datum 21 above, the antonyms "native" and "alien" are used. The input spaces are "native executhieves" and "alien wolve'. An attribute of "native executhieves" (corrupt leaders) is mapped unto "alien wolves" to create the blend that exploitation of the country's resources which has penuried the masses is a collaborative work between the corrupt leaders and foreigners of their kind; their involvement gives the foreigners the impetus and opportunity to carry out their nefarious and exploitative enterprise. Through this, Osunadare takes a swipe at the corrupt leaders who are supposed to care for the masses but oppress them and even give room to foreigners for more exploitation and plundering of the nation's resources. This is to awaken the people's consciousness of the exploitation of the nation's resources by their leaders and to act towards achieving a change.

with our earth so warm

how can our hearth be so cold? ("Harvestcall" St.9 line 6,7)

In datum 22, the antonyms "warm" and "cold" are used. The input spaces are "warm earth" and "cold hearth". The author through contrast highlights an abnormality in our "hearth" which does not correspond with what the "earth" holds. The input spaces are a "warm earth" and a "cold hearth" which create a blend of an abnormal situation where the people live in lack whilst the earth holds so much for their use. Osundare informs that the people's plights 
Volume 1 Number 2

are man-made and self-induced because all they will need is available but only needs 'the waking finger of the seasoned tapper' to enjoy these benefits

Only a membrane very thin

Separate your sheepish grin

From your wolfish insides. ("Tell them, Mandela")

In datum 23 above, the opposites "sheepish" and "wolfish" are used to communicate some message. The opposites "sheepish grin (appearance)" and "wolfish insides (reality)" are also the input spaces from which the author maps out some attributes to the people being referred to. From the input space "sheepish", the author maps out an attribute of "innocence" and from the input space "wolfish", the author maps out an attribute of "danger" to the people referred to. The two opposites refer to the same set of people to bring to the fore their doublesidedness. Through the input spaces, the author creates the blend that reveals the dangerousness of the inside of the people (referred to) even though they appear innocent and friendly. Through this, the author explores the theme of pretense and deceit where the people (referred to) are outwardly friendly but inwardly wicked and are deceiving the people by pretending to be who they are not. The author, through this condemns pretense and preaches sincerity where everybody will be known for who he is.

From the analysis, it is shown that writers carefully choose stylistic devices that help to convey their message to readers. This is seen in stylistic devices such as personification, parallel construction, metaphor, simile, rhetorical question etc. These devices used by Osundare constitute a means of drawing the attention of Nigerians and outsiders to the various vices; injustices, corruption, greed, self-aggrandisement, etc. being perpetuated in the society. Beyond unearthing these societal ills, the poet through the deployment of these stylistic devices seeks to cause a change that will bring about a sane society where everybody is treated fairly regardless of their ethnic, political, religious and economic status. The aim is towards an egalitarian society where there is even distribution of the nation's natural resources and wealth and everybody is equal before the law; a place where the earth's various resource are used judiciously. Sometimes, people are aware that they have societal problems but may not know the source of those problems or take upon themselves to find out and may be reluctant towards rising to the occasion and fighting their way out of the problems especially when they are caused by their self-chosen leaders who use their privileged positions and authority to oppress them. Thus, ultimately, these societal ills are revealed to incite revolution to cause a change.

\section{CONCLUSION}

This study has attempted to show that Osundare through the use of some stylistic devices whose inherent meanings could be unearthed through the blending approach, seeks to condemn apathy and incite readers to rise up against societal ills and injustices meted out to them especially by those in positions of authority. It has also been shown that within the literary stylistics scope, Osundare's The Eye of the Earth is replete with literary stylistic devices such as simile, metaphor, parallel constructions, personification, repetition, alliteration, interrogation/rhetorical question and antonymy/antithesis which aided the meaning-making process and the projection of his message to readers. Specifically, it is revealed that The Eye of the Earth is targeted towards having an egalitarian society and a healthy environment. It is noteworthy that while an attempt was made in this study to class Osundare as an ace stylistician, keen attention was paid to the impact of his poetry collection on the readers and by extension, the society. 


\section{REFERENCES}

Abrams, M. H (1999). Marxist Criticism: A Glossary of Literary Terms. Ed. (Wadsworth: Harcourt Brace College Publishers.

Asika, I. (2012). The Writer as a Patriot: Marxist and Marxist Consciousness in Festus Iyayi's Violence The ideal Man: Festcrift in Honour of Professor Obed Mojekwu Anizoba. Akwa: Apple Books Publishers.

Asika, I. (2014). Protest and Praxis in African Literature: a Marxist Reading of Ngugi Wa Thiongo's Wizard of the Crow. Retrieved on 20 August, 2017 from: www.questjournals.org.

Carter, R. and Simpson, P. (1989) Language, Discourse and Literature: An Introduction to Discourse Stylistics. London: Unwin Hyman.

Chinaka, M and Oyebuchi, O. (2014). Revolutionary Impulse in Selected Poems of Hope Eghagha. Journal of Integrative Humanism - Ghana, 2026-6286.

Halliday, M.A.K. (2009). The Essential Halliday New York: Continuum International.

Halliday, M. A. K. (2007). Language and Education. London: Continuum.

Halliday, M.A.K. \& Hassan, R. (1976). Cohesion in English. London: Longman.

Halliday, M.A.K. (1974). Language and Social Man. London: Longman

Halliday, M.A.K. (1973). Explorations in the Functions of Language. London: Edward Arnold.

Halliday, M.A.K., Matthiessen, C.M.I.M. (1999). Construing Experience through Meaning: a Language-based Approach to Cognition. London: Cassell.

Kehinde, Ayo. (2005). Rethinking African Fiction in the Era of Globalization: A Contest of Text and Context. Journal of the Nigerian English Studies Association 11.1: 87-100.

Leech, G.N. (1966). English in Advertising. London: Longman

Myers, J. and Simms, M. (1989).The Longman Dictionary of poetic Terms. New York and London: Longman

Norgaard, N.,Montorio, R. and Busse, B. (2010).Key Terms in Stylistics. New York; Continuum Int. Publishing Group.

Odebunmi, A. (2001). Meaning in English: An Introduction. Ogbomosho: critical Sphere.

Okunowo, Y. (2012). patterns of parallelism as trope of meaning in Osundare's poetry. Academic Research International Vol. 2, No. 2, March Retrieved on $14^{\text {th }}$ March, 2018.

Osundare, Niyi. (2008): The Writer as Righter. Ibadan: Hope Publications. 
Osundare, Niyi. (2014). Merit Award Won't Silence me as Critic. The Guardian Newspapers. Retrieved August 20, August from: www.ngrguardiannews.com/news/nationalnews/ 191915-merit-award-won’t-silence-me-as-critic-says-osundare

Owonibi, S.(2014).The Political Consciousness in African Literature: A Reading of Selected Plays of Femi Osofisan. European Scientific Journal, July 2014 edition, vol.10, No.20.

Simpson, P. (2004): Stylistics: A Resource Book for Students. London: Routledge Publishers

Wales, K. (2001). A Dictionary of Stylistics. England: Pearson Education. 